\title{
AVAILABILITY OF THE MOTORWAY EMERGENCY COMMUNICATIONS
}

\section{GOTOWOŚĆ SYSTEMU AUTOSTRADOWEJ ŁĄCZNOŚCI ALARMOWEJ}

\author{
Mirosław Siergiejczyk ${ }^{1}$ \\ (1) Warsaw University of Technology, Faculty of Transport \\ Politechnika Warszawska Wydzial Transportu \\ 00-662 Warsaw Koszykowa 75 \\ e-mail: msi@it.pw.edu.pl
}

Summary. The paper presents issues related to the assessment of availability of one of the motorway telematics systems: the emergency communication system. The essence and tasks of transport telematic systems have been presented in a general outline. The architecture of the fibre optic emergency communication system and the tasks of particular subsystems have also been presented. Using the functional structure and the method of sending information through the system, a method for calculating the availability of the motorway emergency communication system was proposed.

Key words: telematics, transport, communication system, availability.

Streszczenie. $\mathrm{W}$ referacie przedstawione zostały zagadnie związane $\mathrm{z}$ ocena gotowości jednego z systemów telematyki autostradowej, systemu łączności alarmowej. W ogólny sposób opisano istotę i zadania systemów telematyki transportu. Przedstawiona została architektura światłowodowego systemu łączności alarmowej i opisane zostały zadania poszczególnych podsystemów. Wykorzystując strukturę funkcjonalną $\mathrm{i}$ sposób przesyłania informacji w systemie zaproponowano sposób obliczania gotowości systemu autostradowej łączności alarmowej.

Słowa kluczowe: telematyka, transport, system łączności, gotowość. 


\section{AVAILABILITY OF THE MOTORWAY EMERGENCY COMMUNICATIONS}

\section{Introduction}

The use of telematics for systems comprising a large number of dispersed elements is aimed at ensuring communication between the users and the environment. The key function of telematic systems is handling information, i.e. obtaining, processing, distributing (including transmission) and using data in decision processes. The processes may be carried out in a predetermined manner (e.g. automatic steering), or may result from events that arise at given moments (disposers', dispatchers', independent infrastructure users' decisions) [4].

Transport telematics cover issues related to integrated telecommunications, IT and information systems, and specifically those relating to hardware and software systems used in transport. Transport telematic solutions may be applied for an isolated type of transport on a specific area or may be realized and integrated at the national or international level. Such solutions have to be scaleable to enable their extension, modernization and supplementation. Their purpose should be ensuring such cooperation of particular components of the system and interaction with the users as will guarantee higher safety of travel and transport, greater reliability of transport, more efficient use of infrastructure and achieving better economic results, as well as limiting the degradation of the environment.

One of the more important uses of the above-mentioned systems is transport. Transport telematics constitute a branch of knowledge and technical activities that integrate computer information with telecommunications and apply them to transport systems. They comprise transport supported by the use of integrated measurement, telecommunication, IT and information systems and by telematic applications (services) [3].

\section{Motorway telematics}

Motorway telematics is the use of intelligent transport systems on motorways in order to significantly increase the safety of travel and 
transport, including reducing the degradation of the environment, increasing transport reliability, better use of infrastructure and achieving better economic results.

Motorway telematics constitute a management centre for transport, passenger, vehicle and driver traffic, and for the movement of goods, but are also used to include vehicles (cars, coaches, etc.) in computer networks, mobile telephone systems networks, GPS, and to equip vehicles and parcels with appropriate sensors.

An Intelligent Telematic Transport System, the subsystem for road, vehicle, driver and transport services management, based on real-time telecommunication, creates a logical sequence enabling managing the translocation of people, vehicles and goods in verifiable environmental conditions [2].

Motorway telematics is an issue of special interest. Currently, the development of road transport, and specifically motorway transport, is a priority in Poland. The traffic is already so dense that without intensive actions aimed at constructing and extending motorways the country is faced with communication paralysis. Therefore, the problem of motorway transport should be the focus of scientists' interests [3].

Secondly, a motorway without the appropriate telematic equipment tailored to the requirements of the anticipated and existing traffic parameters, territorial routes, the existing threats and many other factors, would not meet the expectations of users, which would lead to the motorway being unsafe and economically ineffective.

Thirdly, motorway telematic systems and the services they provide cover so many areas of technology and user solutions that we may risk saying that they are also representative for many other solutions in other types of transport [3].

\section{Architecture of the motorway emergency communications system}

The motorway emergency communications systems are used to transmit reports about breakdowns, accidents, etc. from users in a given section of the motorway to the motorway section supervision stations.

Equipping an emergency sensor pole enables two-way communications (signalling emergency and audio monitoring) or one-way communications (only signalling emergency using the emergency button for requesting help). By pushing the emergency button in the motorway sensor pole, the system user causes the notification to be sent to the Supervision System. The 
message sent includes the address identifying the sensor pole. Thanks to this the area and network geometry at the place of the event are known. The operator recognizes the number and position of the emergency pole from which the signal has been sent and may quickly notify appropriate services and remotely activate a blinking light installed in the emergency pole. In case of a two-way communication, he connects with the pole from which the emergency signal was sent and speaks to the user.

The discussed system of motorway emergency communications between the network nodes is a solution in which a fibre optic cable is used laid in the ground along the motorways. It ensures resistance to environmental electromagnetic interference which would lower the quality of services and provides a large capacity of the breadth of the fibre optic band. The system was designed so as to ensure not only support for emergency communications but also free transmission of data (4800 bodes) for road equipment.

The fibre optic emergency communication system comprises the following subsystems (Fig 1):

- The Supervision Centre (CCS) which manages user notifications, sustains calls in the event of many users calling, automatically dials the pre-programmed PSTN numbers,

- The opto-electric interface called the Central Access Point (CAP) which enables two-way transmission over the optic fibre,

- Networks of passive transoptors attached to the fibre optic cable intended for the fibre optic system of emergency notification system. They enable connecting all emergency poles on the same branch using one fibre per branch.

- The transoptor interface, the so-called FOB - Field Optical Box, attributed to each pair of emergency poles and connected to the main pole.

- The connections between FOB and the main emergency pole use a short multipair cable to facilitate maintenance intervention in case of damage to the emergency pole e.g. by a vehicle driving into it.

- Emergency poles (main and subordinate) which are placed along the motorway on both sides, constituting branches leading to the Supervision Centre. Emergency poles consist mainly of electronic systems (an amplifier of audio frequency, circuit input, audio system with a microprocessor, modem and interface) a microphone, loudspeaker, and emergency button. 


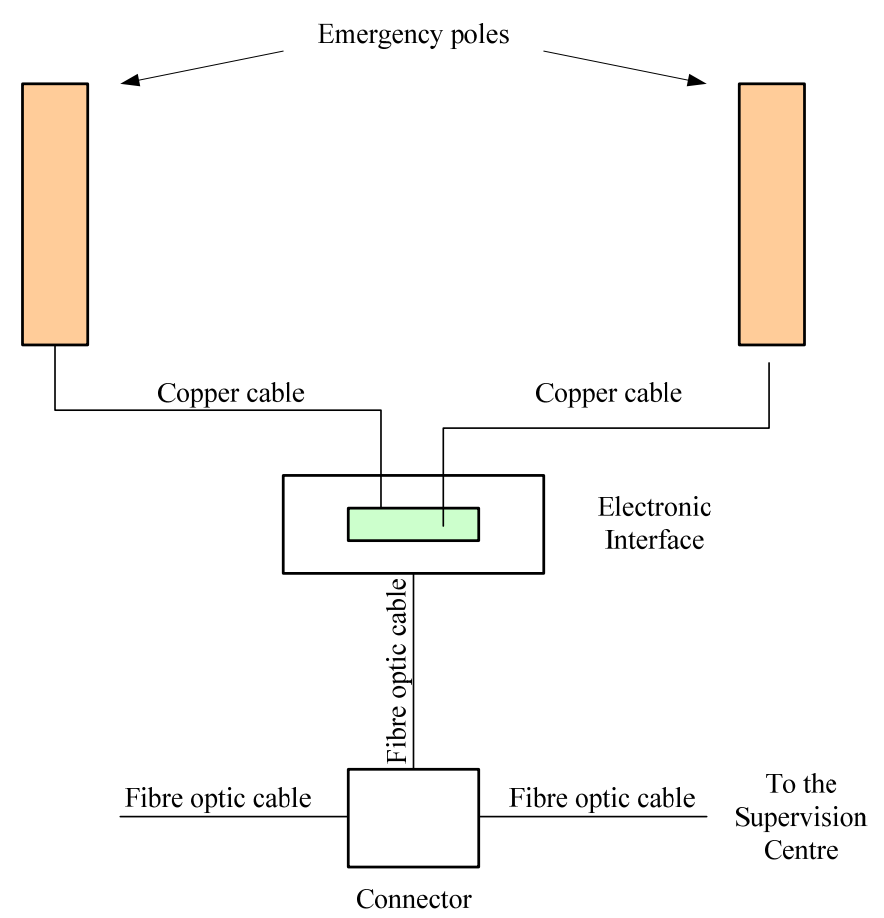

Fig 1. Emergency communication network architecture

Implementing a solution fully based on fibre optic cables leads to a significant cost reduction, especially of public works, laying and joining cables in road projects.

\section{Availability of the motorway emergency communication system}

In a telecommunication network (including an emergency communication network) availability, i.e. a property of the network consisting of its ability to ensure making and maintaining a connection between active subscribers at a given time and in existing conditions for use, is the result of the availability of its particular components and the operational and reliability structure of the network.

Availability is one of the basic reliability ratios of a technical facility; therefore also of the telecommunication system and network which results from the properties of use. Availability may be defined as the ability of a facility to maintain stand-by availability to perform the required functions in given conditions, in a given moment or a given period assuming that the required external factors are provided. If we refer the term "availability" to a 
technical facility such as a telecommunications network, ex definitione, we can see that availability depends on technical services which in turn are strictly related to:

- availability at a given moment, i.e. the chance that when there is demand for a telecommunication service the network will be able to perform it;

- operating availability of the network, i.e. the chance that it is on standby, therefore available.

To conclude, telecommunication devices and transmission routes should be ready (available) when there is demand for a service, and should not break down over the time needed to complete the service. Availability refers to the capability of telecommunication devices and transmission routes, including telecommunication lines, to provide the services resulting from user demand To a large extent, availability of a network depends on its potential damageproofness and serviceability of the telecommunication devices and transmission routes, as well as the selection of the usage process, and specifically managing the use and technical servicing of the telecommunication network.

Availability of a network may be measured using various ratios whose value depends mainly on:

- the course of the process of damaging telecommunication devices and transmission routes which are part of the network,

- the course of the process of servicing nodes (commuter systems) and telecommunication routes which is imposed by the adopted philosophy of service policy,

- the course of the service system operating process.

The parameter which is very often and readily used to assess telecommunication networks in respect of their capability to complete the service is availability. As specified before, temporary availability is the probability that the facility is unable to fulfil a given function in given conditions at a given moment, and stationary availability can be expressed as the average value of the temporary availability in stationary conditions in a given time bracket. The coefficient is not calculated for the whole network but for a few selected telecommunication chains. To ensure that the value is not burdened with too big an error, the fragment of the network between two specific pairs of devices which send data to each other should be analyzed.

Calculating availability should be an iterative process taking into consideration all material factors referred to above having an impact on the network's ability to complete services. The first step is the calculation of 
particular elements, then the interconnections between those elements have to be taken into account, and the repair procedures, and then the availability of the whole chain should be calculated [1].

In practice, this may often be a very complex task, additionally made more difficult by - for example - uneven dispersion of traffic which should also be taken into consideration. It follows from analysis of literature that the time needed to perform such calculations depends exponentially on the size of the network, and completing them without computer tools is nowadays impossible.

Taking into consideration the knowledge of the operational and reliability structure of the network nodes, i.e. the system of emergency poles and the terminal of the dispatcher in the Supervision Centre, as well as knowledge of the reliability structure of the bipolar network between the two nodes, availability of the emergency communication network for the transmission of messages from one emergency pole system to the Supervision Centre may be expressed in the form of a general dependence:

$$
A_{K C}(t)=A_{K A}(t) \times A_{K T}(t) \times A_{T C N}(t)
$$

where: $A_{K C}(t)$ - availability of the emergency communication network between a single emergency pole system and the terminal at the Supervision Centre, $A_{K A}(t)$ - availability of an emergency pole system, $A K C(t)$ - availability of fibre optic connection between a single emergency pole system and the terminal of the dispatcher station at the Supervision Centre,

$A_{T C N}(t)$ - availability of the terminal of the dispatcher station at the Supervision Centre.

An important issue related to calculating the reliability of the emergency communication network is the assessment of the reliability of the terminal at the dispatcher's station. Equipping an emergency pole consists of electronic components installed on one plate. In case of damage the plate is replaced; therefore, the model of durability of an electronic device may be used to analyze reliability. The dispatcher's station at the emergency communication Supervision Centre is built based on a PC-class computer added to the set of emergency connections. Each set consists of one central unit and branch units in series. In this case, to test reliability methods used in microprocessor systems have to be used which take into consideration the reliability of both the hardware and the software.

Availability may then be calculated using the following dependence: 


$$
A_{K T}=A_{K} \times A_{\text {trans }}^{2} \times A_{\text {treg }}^{n} \times A_{w z m}^{m}
$$

assuming that:

$A_{K T}-$ line availability,

$A_{K}$ - fibre optic cable availability,

$A_{\text {trans }}$ - broadcasting and receiving transponder availability,

$A_{\text {reg }}$ - availability of a single regenerator,

$A_{w z m}$ - availability of a single amplifier,

$\mathrm{n}$ - number of regenerators in the analyzed line,

$\mathrm{m}$ - number of amplifiers in the analyzed line.

As already mentioned above, such elements as cables also have an impact on the availability of the whole line; their availability is calculated using the Cable Cut (CC) parameter which represents the average length of a cable that is ruptured once during one whole year $(8760 \mathrm{~h})$. The $\mathrm{CC}$ ratio is expressed in kilometres, and the value of the $M T B F_{K}$ parameter for a cable with a length of $L$ is expressed in hours and amounts to [1]:

$$
\operatorname{MTBF}_{K}(L)=\frac{C C \times 8760}{L}
$$

\section{Conclusion}

It follows from the discussion that the following postulates are important for this type of communications network: ensuring high reliability of elements constituting nodes (emergency poles, dispatcher station terminals) and developing such a reliability structure of the network so as to ensure that its impact on the reliability of information transmission is minimal. This leads to a recommendation to use the minimum possible distances between the network nodes. The second recommendation may be presented as an attempt to resolve the issue of allocation of the reliability requirements in respect of particular internodal links in the network using the function $\mathrm{R}_{\mathrm{a}, \mathrm{b}}\left\{\varphi\left(\mathrm{x}^{*}\right)=1\right\}$ $=\mathrm{f}(\lambda / \mathrm{km})$, where $\lambda / \mathrm{km}$ constitutes the intensity of damage of one kilometre of the internodal transmission line in use.

In practice, this may often be a very complex task, additionally made more difficult by - for example - uneven dispersion of traffic which should also be taken into consideration. It follows from analysis of literature that the time needed to perform such calculations depends exponentially on the size of the network, and completing them without computer tools is nowadays impossible. 


\section{Refereces}

1. Chołda P., Jajszczyk A.: Ocena gotowości $w$ sieciach telekomunikacyjnych (Evaluation of availability of telecommunication networks). Przeglad Telekomunikacyjny and Wiadomości Telekomunikacyjne. No. 2-3/2003. Pub. Sigma NOT Warsaw 2003.

2. Klein L.A.: Sensor Technologies and date requirements if ITS. Artech Hause, ITS Library, 2001.

3. Wawrzyński W., Siergiejczyk M. and others: Metody wykorzystania środków telematyki we wspomaganiu realizacji zadan transportowych. (Methods of usage of telematics means in supporting fulfilment of transport tasks). Report from KBN grant 5T12C 066 25. Warsaw 2006.

4. Wydro K. B.: Telematyka- znaczenia i definicje terminu (Telematics meainings and definitions of the term). Telekomunikacja i Techniki Informacyjne. Pub. Instytut Łączności, Warsaw 2005. 


\section{GOTOWOŚĆ SYSTEMU AUTOSTRADOWEJ LĄCZNOŚCI ALARMOWEJ}

\section{Wstęp}

Zastosowania systemów telematycznych dla systemów składających się $\mathrm{z}$ dużej liczby elementów, rozproszonych przestrzennie, mają na celu zapewnienie komunikacji między użytkownikami a otoczeniem. Najważniejszą funkcją systemów telematycznych jest operowanie informacja, czyli pozyskiwanie, przetwarzanie, dystrybucja z transmisja i wykorzystanie danych $w$ procesach decyzyjnych. Procesy mogą być realizowane $\mathrm{W}$ sposób $\mathrm{z}$ góry zdeterminowany (np. automatyczne sterowanie), bądź wynikać z sytuacji doraźnych (decyzje dysponentów, dyspozytorów, niezależnych użytkowników infrastruktury) [4].

Telematyka transportu obejmuje dziedzinę zajmującą się zintegrowanymi systemami telekomunikacyjnymi, informatycznymi i informacyjnymi, w szczególności wyposażeniowo - systemowymi i programistycznymi wykorzystywanymi $\mathrm{W}$ transporcie. Rozwiązania telematyki transportu swoim zasięgiem mogą być realizowane zarówno dla wyodrębnionego rodzaju transportu na wybranym obszarze jak też mogą być realizowane $\mathrm{i}$ integrowane na poziomie krajowym lub międzynarodowym. Rozwiązania takie muszą być skalowalne, aby mogły być rozbudowywane, modernizowane i uzupełniane. Ich celem powinno być zapewnienie takiego współdziałania poszczególnych elementów systemu i interakcji z użytkownikami, które zapewniać będzie zwiększenie bezpieczeństwa podróży i przewozów, zwiększenie niezawodności transportu, lepsze wykorzystanie infrastruktury i uzyskanie lepszych wyników ekonomicznych, a także ograniczenie degradacji środowiska.

Jednym z ważniejszych zastosowań wyżej omówionych systemów jest transport. Telematyka transportu jest dziedziną wiedzy i działalności technicznej integrującą informatykę $\mathrm{z}$ telekomunikacją $\mathrm{w}$ zastosowaniu do systemów transportowych. Jest to transport wsparty zastosowaniem ziniegrowanych systemów pomiarowych, telekomunikacyjnych, informatycznych, informacyjnych oraz aplikacjami telematycznymi (usługami) [3].

\section{Telematyka autostradowa}

Telematyka autostradowa to zastosowanie systemów inteligentnego transportu na autostradach w celu znaczącego zwiększenie bezpieczeństwa 
podróży i przewozów, przy tym zmniejszenie degradacji środowiska, zwiększenie niezawodności transportu, lepsze wykorzystanie infrastruktury i uzyskiwanie lepszych wyników ekonomicznych.

Telematyka autostradowa obejmuje centrum zarządzania transportem, ruchem pasażerów, pojazdów, kierowców, towarów, ale również włączenie pojazdów (samochody, autokary itd.) w sieć komputerową, sieć telefonii komórkowej, GPS, wyposażenie pojazdów czy przesyłek w odpowiednie sensory. Inteligentny Telematyczny System Transportowy, podsystem zarządzania drogą, pojazdem, kierowca, usługą transportową w oparciu o telekomunikację czasu rzeczywistego, tworzą logiczny ciąg umożliwiający panowanie nad przemieszczaniem ludzi, pojazdów i towarów w zmiennych warunkach środowiska [2].

Przedmiotem szczególnego zainteresowania jest system telematyki autostradowej. Uznano, że w obecnie rozwój transportu drogowego, a szczególnie autostradowego $\mathrm{w}$ Polsce jest problemem priorytetowym. Gęstość ruchu bowiem na drogach krajowych osiagnęła takie rozmiary, że bez intensywnych działań w kierunku budowy i rozbudowy autostrad grozi krajowi paraliż komunikacyjny. Zatem problematyka transportu autostradowego winna być w centrum zainteresowania naukowców [3].

Po drugie autostrada bez należytego wyposażenia telematycznego dostosowanego do potrzeb wynikających ze spodziewanych i istniejących parametrów ruchu, jej przebiegu terytorialnego, istniejących zagrożeń i wielu innych czynników nie spełnia oczekiwań użytkowników i eksploatatorów powodując, że użytkowanie takiego rozwiązania jest i niebezpieczne i mało efektywne ekonomicznie.

Po trzecie wszakże systemy telematyki autostradowej i usługi które one realizują obejmują tak wiele dziedzin techniki i rozwiązań użytkowych, że można zaryzykować twierdzenie o ich reprezentatywności wobec wielu innych rozwiązań w innych rodzajach transportu [3].

\section{Architektura systemu autostradowej lączności alarmowej}

System autostradowej łączności alarmowej służy do przekazywania zgłoszeń od użytkowników znajdujących się na danym odcinku autostrady do stacji nadzoru odcinka autostrady o awariach, kolizjach itp.

Wyposażenie kolumny umożliwia łączność dwukierunkową (zasygnalizowanie zgłoszenia i odsłuch akustyczny) lub jednokierunkową (tylko zasygnalizowanie zgłoszenia przyciskiem wzywania pomocy). Użytkownik systemu uruchamiając przycisk wzywania pomocy w kolumnie autostradowej powoduje emisję wiadomości do Centrum Nadzoru. Wysłana 
wiadomość zawiera adres identyfikujący kolumnę alarmową. Dzięki temu od razu znany jest obszar i geometria sieci w miejscu zdarzenia. Operator rozpoznaje numer i położenie kolumny, z której pochodzi wezwanie i może szybko zawiadamiać odpowiednie służby i zdalnie uruchomić migające światło zainstalowane na kolumnach. W przypadku łączności dwukierunkowej łączy się z kolumną, z której pochodzi wywołanie alarmowe i przeprowadza rozmowę z użytkownikiem.

Analizowany system autostradowej łączności alarmowej jest rozwiązaniem, w którym do transmisji pomiędzy węzłami sieci wykorzystuje się kabel światłowodowy ułożony w ziemi wzdłuż autostrad. Zapewnia to odporność na środowiskowe zakłócenia elektromagnetyczne, które powodują obniżenie jakości usług oraz dużą pojemność szerokości pasma medium światłowodowego. System tak zaprojektowano, aby oprócz wspomagania łączności alarmowej zapewniał także wolną transmisję danych (4800 bodów) dla wyposażenia drogowego.

Światłowodowy system łączności alarmowej składa się z następujących podsystemów (rys.1):

- Centrum Nadzoru (CCS) zarządzające zgłoszeniami użytkownika, podtrzymujące rozmowy w przypadku wielu użytkowników, automatyczne wybierania zaprogramowanych numerów PSTN,

- Urządzenia interfejsu optoelektrycznego, zwanego punktem centralnego dostępu CAP (Central Access Point), które umożliwia transmisję dwukierunkową po kablu światłowodowym,

- Sieci biernych sprzęgaczy optycznych dołączonych do kabla światłowodowego przeznaczonego dla światłowodowego systemu łączności alarmowej. Pozwalają one na połączenie wszystkich kolumn alarmowych na tym samym odgałęzieniu $\mathrm{z}$ wykorzystaniem jednego włókna na odgałęzienie.

- Interfejs elektrooptyczny, tzn. optyczna skrzynka terenowa FOB- Field Optical Box), przyporządkowana każdej parze kolumn alarmowych i dołączona do kolumny głównej. Połączenia między FOB i główną kolumną alarmową dokonuje się za pomocą krótkiego kabla wieloparowego, aby ułatwić interwencję utrzymaniową w przypadku uszkodzenia kolumny przez np. uderzenie pojazdu.

- Kolumny alarmowe (główne i podrzędne), które znajdują się wzdłuż autostrady po obu stronach tworząc odgałęzienia do Centrum Nadzoru. Kolumny alarmowe główne składają się z układu elektronicznego (wzmacniacz częstotliwości akustycznej, wejście łącza, układ akustyczny $\mathrm{z}$ mikroprocesorem, modem i interfejs), mikrofonu, głośnika i przycisku alarmowego. 


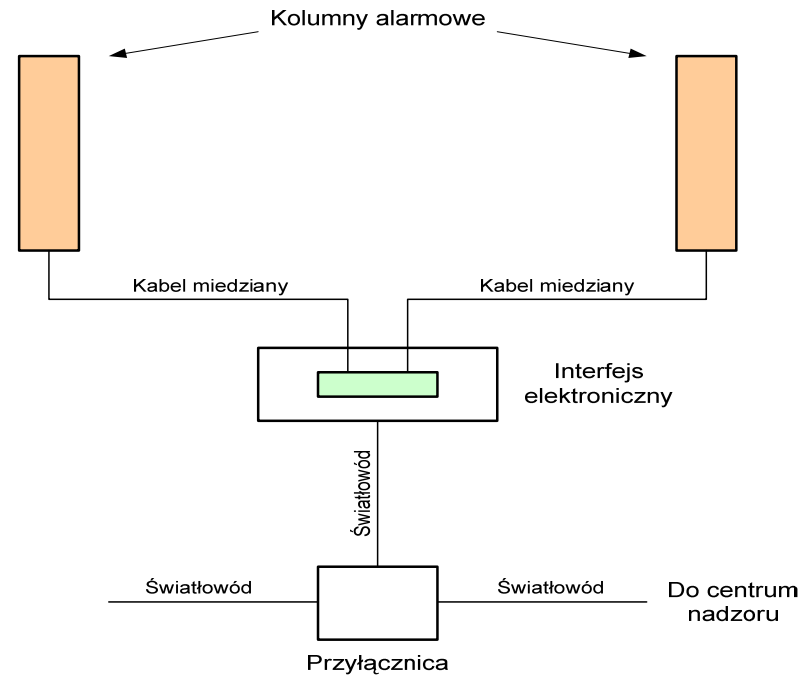

Rys.1. Architektura sieci łączności alarmowej

Wprowadzenie rozwiązania w pełni opartego na światłowodzie prowadzi do znaczącego obniżenia kosztów, zwłaszcza robót publicznych, układania i łączenia kabli w przedsięwzięciach drogowych.

\section{Gotowość systemu autostradowej lączności alarmowej}

$\mathrm{W}$ sieci telekomunikacyjnej ( $\mathrm{w}$ tym w sieci łączności alarmowej) gotowość, czyli własność sieci polegająca na zdolności do zapewnienia zestawienia i utrzymania połączenia pomiędzy aktywnymi abonentami w określonym czasie i istniejących warunkach eksploatacji jest wynikiem gotowości poszczególnych jej elementów składowych oraz struktury funkcjonalno-niezawodnościowej sieci.

Gotowość (ang. availability) zwana też dyspozycyjnością jest jednym z podstawowych wskaźników niezawodnościowych obiektu technicznego, a więc także systemu i sieci telekomunikacyjnej, który wynika z właściwości użytkowania. Gotowość można zdefiniować jako zdolność obiektu do utrzymania się $\mathrm{w}$ stanie umożliwiającym wypełnianie wymaganych funkcji $\mathrm{w}$ danych warunkach, w danej chwili lub $\mathrm{w}$ danym przedziale czasu przy założeniu, że są dostarczone wymagane środki zewnętrzne. Jeśli odniesiemy pojęcie gotowości do obiektu technicznego, jakim jest sieć telekomunikacyjna, $\mathrm{z}$ definicji otrzymamy zależność gotowości od obsługiwania technicznego, która ściśle wiąże się z:

- gotowością w danej chwili czyli szansą, że w chwili wystapienia zapotrzebowania na wykonanie usługi telekomunikacyjnej, sieć ta będzie zdatna, do jej wypełnienia, 
- gotowością operacyjną sieci, czyli szansą, że znajduje się ona w stanie oczekiwania, inaczej jest dostępna.

Reasumując urządzenia telekomunikacyjne i drogi przesyłowe powinny być zdatne (gotowe) w momencie wystapienia zapotrzebowania na wykonanie usługi i nie uszkodzą się przez cały czas potrzebny na jej realizację. Gotowość odnosi się do zdatności urządzeń telekomunikacyjnych i dróg przesyłowych, w tym linii telekomunikacyjnych, do realizacji usług wynikających z zapotrzebowania użytkowników.

W znacznej mierze gotowość sieci zależy od potencjalnej nieuszkadzalności i podatności obsługowej urządzeń telekomunikacyjnych i dróg przesyłowych, oraz wyboru relacji procesu eksploatacji, a szczególnie zarządzania użytkowaniem i obsługiwaniem technicznym sieci telekomunikacyjnej.

Gotowość sieci można mierzyć stosując różne wskaźniki, których wartości zależą głównie od

- przebiegu procesu uszkadzania się urządzeń telekomunikacyjnych i dróg przesyłowych, które wchodzą w skład sieci,

- przebiegu procesu obsługiwania węzłów (systemów komutacyjnych) i traktów telekomunikacyjnych, który jest narzucony przez przyjętą filozofię polityki obsługiwania,

- przebiegu procesu funkcjonowania systemu obsługi.

Bardzo często i chętnie używanym parametrem do oceny sieci telekomunikacyjnych $\mathrm{w}$ aspekcie zdolności do realizacji usług jest gotowość. Jak określono wcześniej, gotowość chwilowa to prawdopodobieństwo, że obiekt jest w stanie wypełniać wymaganą funkcję $\mathrm{w}$ danych warunkach $\mathrm{w}$ danej chwili, zaś gotowość stacjonarna to inaczej średnia wartość gotowości chwilowej w warunkach stacjonarnych w danym przedziale czasu. Współczynnika tego nie oblicza się dla całości sieci, lecz dla wybranych łańcuchów telekomunikacyjnych. Aby obliczona wartość nie była obarczona zbyt dużym błędem, rozpatrywać należy fragment sieci między określonymi parami urządzeń przesyłających sobie wzajemnie dane. Obliczenie gotowości powinno przebiegać w sposób iteracyjny, uwzględniający wszystkie istotne, wymienione wcześniej czynniki, mające wpływ na zdolność sieci do realizacji usług. W pierwszym kroku oblicza się gotowość poszczególnych elementów, następnie należy uwzględnić połączenia tych elementów oraz stosowane procedury naprawcze i obliczyć gotowość całego łańcucha [1].

W praktyce, może to być niejednokrotnie zadanie bardzo złożone, dodatkowo utrudniane na przykład przez nierównomierny rozkład ruchu, który powinien również zostać uwzględniony. Z analizy literatury wynika, 
że czas takich obliczeń zależy wykładniczo od rozmiarów sieci, a wykonanie ich bez narzędzi informatycznych jest w dzisiejszych warunkach wręcz niemożliwe.

Uwzględniając znajomość struktury funkcjonalno-niezawodnościowej węzłów sieci czyli, zespołu kolumn alarmowych i terminala stanowiska dyspozytorskiego w Centrum Nadzoru oraz znajomość struktury niezawodnościowej dwubiegunowej sieci pomiędzy tymi węzłami, gotowość sieci łączności alarmowej dla transmisji wiadomości z jednego zespołu kolumny alarmowej do Centrum Nadzoru można zapisać w postaci ogólnej zależności:

$$
A_{K C}(t)=A_{K A}(t) \times A_{K T}(t) \times A_{T C N}(t)
$$

gdzie: $A_{K C}(t)$ - gotowość sieci łączności alarmowej pomiędzy pojedynczym zespołem kolumn alarmowych a terminalem w Centrum Nadzoru, $A_{K A}(t)$ - gotowość zespołu kolumn alarmowych, $A_{K T}(t)$ - gotowość łącza światłowodowego pomiędzy pojedynczym zespołem kolumn alarmowych a terminalem stanowiska dyspozytorskiego w Centrum Nadzoru,

$A_{T C N}(t)$ - gotowość terminala stanowiska dyspozytorskiego w Centrum Nadzoru.

Ważnym zagadnieniem związanym $\mathrm{z}$ obliczeniem niezawodności sieci łączności alarmowej jest oszacowanie niezawodności kolumny alarmowej i terminala stanowiska dyspozytorskiego. Wyposażenie kolumny składa się z elementów elektronicznych montowanych na jednej płycie. W przypadku uszkodzenia płyta jest wymieniana, można więc do analizy niezawodności przyjąć model trwałości urządzenia elektronicznego. Stanowisko dyspozytorskie w Centrum Nadzoru łączności alarmowej zbudowana jest w oparciu o komputer klasy PC dołączony do zestawu łączy alarmowych. Każdy zestaw składa się $\mathrm{z}$ jednostki głównej i jednostek odgałęzień szeregowych. W tym przypadku należy do analizy niezawodności przyjąć sposoby stosowane $\mathrm{w}$ systemach mikroprocesorowych uwzględniające niezawodność sprzętu i oprogramowania.

Gotowość wówczas można obliczyć wykorzystując następująca zależność:

$$
A_{K T}=A_{K} \times A_{\text {trans }}^{2} \times A_{\text {treg }}^{n} \times A_{w z m}^{m}
$$

przy założeniu, że:

$A_{K T}$ - gotowość łącza,

$A_{K}$ - gotowość kabla światłowodowego,

$A_{\text {trans }}$ - gotowość transpondera nadawczego i odbiorczego,

$A_{\text {reg }}-$ gotowość pojedynczego regeneratora, 
$A_{w z m}$ - gotowość pojedynczego wzmacniacza,

$\mathrm{n}$ - liczba regeneratorów $\mathrm{w}$ analizowanym danego łączu,

$\mathrm{m}$ - liczba wzmacniaczy w analizowanym łączu.

Jak wspomniano wyżej, na gotowość całego łącza mają również wpływ takie elementy składowe jak kable, których to gotowość oblicza się wykorzystując parametr przecięcia kabla CC (Cable Cut), który wyraża średnią długość kabla, który w ciagu całego roku (8760 godz.) ulega jednemu przerwaniu. Współczynnik $C C$ wyrażamy w kilometrach, zaś wartość parametru $M T B F_{K}$ dla kabla, którego długość wynosi $L$, określany jest $\mathrm{w}$ godzinach i wynosi [1]:

$$
\operatorname{MTBF}_{K}(L)=\frac{C C \times 8760}{L}
$$

\section{Podsumowanie}

Z przedstawionych rozważań wynika, że istotnymi wymaganiami dla tego rodzaju sieci łączności są postulaty: zapewnienia wysokiej niezawodności elementów stanowiących węzły (kolumny alarmowe, terminale stanowisk dyspozytorskich) oraz opracowania takiej struktury niezawodnościowej sieci, aby jej wpływ na niezawodność transmisji informacji był jak najmniejszy. Prowadzi to do zalecenia, aby w projektowanej sieci stosować możliwie małe odległości pomiędzy węzłami sieci. Drugie zalecenie można przedstawić jako dażenie do rozwiązania zagadnienia alokacji wymagań niezawodności względem poszczególnych połączeń międzywęzłowych sieci przy wykorzystaniu funkcji $\mathrm{R}_{\mathrm{a}, \mathrm{b}}\left\{\varphi\left(\mathrm{x}^{*}\right)=1\right\}=\mathrm{f}(\lambda / \mathrm{km})$, w której $\lambda / \mathrm{km}$ jest eksploatacyjną intensywnością uszkodzeń jednego kilometra międzywęzłowego toru transmisyjnego.

W praktyce, może to być niejednokrotnie zadanie bardzo złożone, dodatkowo utrudniane na przykład przez nierównomierny rozkład ruchu, który powinien również zostać uwzględniony. $\mathrm{Z}$ analizy literatury wynika, że czas takich obliczeń zależy wykładniczo od rozmiarów sieci, a wykonanie ich bez narzędzi informatycznych jest w dzisiejszych warunkach wręcz niemożliwe.

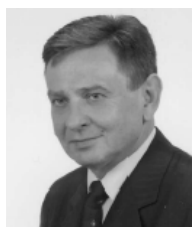

Dr inż. Mirosław Siergiejczyk, Warsaw University of Technology Faculty of Transport Division of Transport Telecommunication,. Assistant Professor, specialization: telecommunications system, reliability and exploitation of telematics transport systems. Several publication in field. 